\title{
Sex matters
}

\section{Shaun McCann ${ }^{1}$}

Received: 26 March 2018 / Accepted: 27 March 2018 / Published online: 4 July 2018

(c) Macmillan Publishers Limited, part of Springer Nature 2018

'A woman drove me to drink and I didn't even have the decency to thank her'.

W.C Fields. American Comedian. 1880-1946.

I'm glad to see that Sherry is making a comeback. I have a propensity for Fino sherry or Manzanilla (made around the port of Sanlúcar de Barrameda). A well chilled Fino sherry goes remarkably well with bone marrow on toast, so I'm told!

For a long time I have believed that women were better wine tasters than men (An Immodest Proposal-Wine and Health. ISBN 978-1-78280-207-5). This belief is also shared by the famous wine critic and writer Jancis Robinson. Writing for the Financial Times in 2004 she said: 'Most of us have heard the pretty conclusive evidence that women are innately more perceptive and reliable wine tasters than men'. Taste and smell are intimately linked and there is no doubt that women have a more acute sense of smell than men. This is particularly true of women in the child-bearing age group and may be linked to reproductive capacity. To test the interconnection between taste and smell try a simple experiment. Pinch your nose and chew an M\& M or some very sweet object. There is practically NO taste. Release your nose from being pinched and suddenly the sweet taste becomes paramount. The same is true for wine, always smell the wine and the cork as this is still the most reliable way of telling if a wine is corked or not (contaminated withTCA,2,4,6-Trichloroanisole).

Happily today many enologists and sommeliers are female and two of my friends in Tuscany, my neighbors Barbara Widmer and Pamela Lenzi, from just outside Siena are both excellent enologists. These are not isolated examples and according to the Wall Street Journal over half the

Shaun McCann

shaunrmccann@gmail.com

1 University of Dublin, Trinity College, Haematology Emeritus, Dublin, Ireland sommeliers in New York are female and the sight of an elderly male sommelier recommending the most expensive wine on the wine list is becoming a thing of the past.

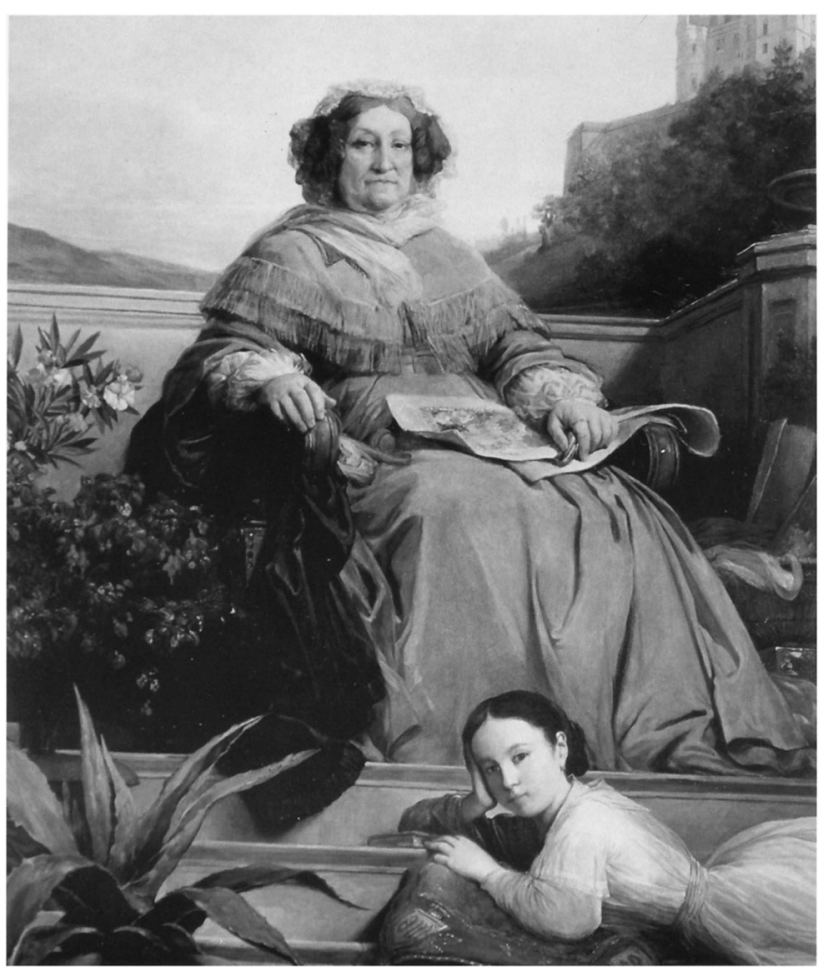

Fig. 1 Madame Clicquot and her great-granddaughter Anne de Rochechouart - Mortemart by Léon Coginet

Madame Clicquot is probably one of the best known female enologists. She was the widow of Barbe-Nicole Ponsardin and is credited with shipping Champagne from France to Imperial Russia in 1811. Prussian soldiers opened Champagne bottles with their swords (Sabring Champagne) a technique not widely practiced today. If you intend to do this to impress your friends I suggest you practice beforehand unless you are skilled in the technique! The Champagne, Veuve Clicquot is well known for its bright yellow label and, of course, for its contents. 
Could there be any scientific explanation for this belief in female wine tasting superiority? In 1961 Mary Frances Lyon, an English Genetisist, published a paper in Nature describing the random $\mathrm{X}$ inactivation of the second $\mathrm{X}$ chromosome in females, subsequently known as the 'Lyon Hypothesis'. In my days as a medical student (the late 1960s) this was portrayed as the explanation for the inheritance of X-linked diseases, such as hemophilia (even though the inheritance pattern of diseases such as hemophilia had been deduced since biblical times).

However, like most scientific discoveries, things are a little more complicated. Carrel and Willard [1], in a letter to Nature, have shown that up to $15 \%$ of $\mathrm{X}$-linked genes escape inactivation and contribute to the phenotype. My bet is that the gene for wine tasting is somewhere among the $15 \%$ of $\mathrm{X}$-linked genes which escape inactivation, thereby explaining the superiority of female wine tasters.

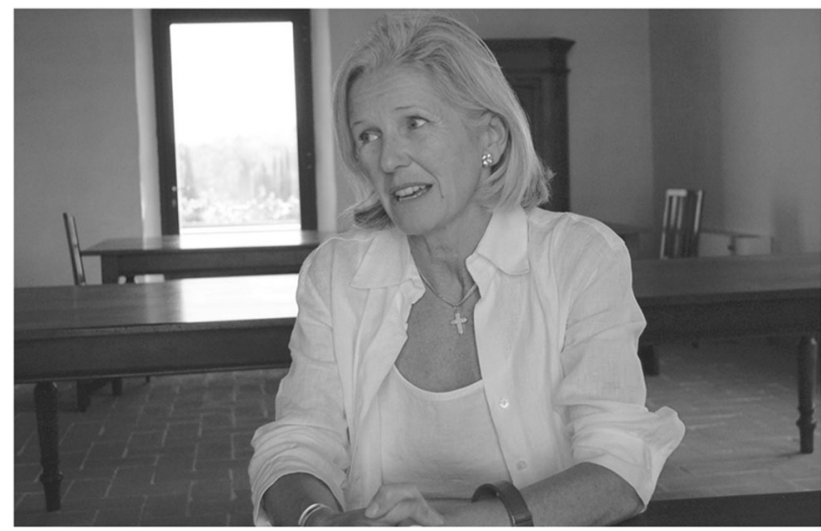

Fig. 2 Elizabetta Gnudi. Winemaker in Tuscany
I always rely on my wife to tell me if a wine is corked and to evaluate the true quality of the beverage.

Shaun McCann is Professor Emeritus of Haematology and Academic Medicine at St James' Hospital and Trinity College Dublin, Ireland. He shares his time between Dublin and Tuscany. He has written a monthly wine article for the Irish Medical Times for over 10 years under the 'nom de plume' Giovanni Morelli.

\section{Compliance with ethical standards}

Conflict of interest As the sole author of this article I have no conflict of interest.

\section{References}

1. Carrel L, Willard HF. X - inactivation profile reveals extensive variability in $\mathrm{X}$ - linked gene expression in females. Nature. 2005;434:400-4. doi: 101038/nature 03479. 